conducted chiefly from the geological standpoint with the view of determining the age of the deposits, and of throwing light upon the much debated question of the oscillations of sea-level in recent times on the Mediterranean seaboard.

Prof. Boule's attention was directed in the first instance to the Grotte du Prince, which was almost intact when excavation was commenced. Here the deposits attain a thickness of more than 20 metres, and consist of basal beds of marine origin upon which strata of continental origin are superimposed. The latter can be subdivided into a number of layers, both by their physical characters and by their fossil contents, but the point of importance is that the upper and middle beds contain remains of reindeer (never previously recorded in this region), ibex, marmot, and woolly rhinoceros, that is, the fauna of the cold period of the Quaternary, while the lower beds contain quite a different fauna-Elephas antiquus, Rhinoceros mercki, and hippopotamus, that is, species belonging to the lower Quaternary fauna. The last named deposits lie upon an old raised beach which is also discernible outside the cavern, along the shore rocks, at a mean altitude of 7 metres. Almost all the contained fossils belong to the existing Mediterranean fauna, but Prof. Boule has found some beautiful examples of 7-metre beach, described at other parts of the Mediterranean littoral by MM. Depéret and Caizot, and regarded by them as of late Quaternary date, really belongs to a much more distant period, for it is anterior to the subaërial deposits containing fossils belonging to the older period of the Quaternary. If this conclusion be correct, it affords a means of fixing the age of the last oscillation of sea-level in this region. It should, however, be noted that in the discussion which followed the reading of the paper $M$. Deperet protested against the proposed homologising of the low raised beach (height $5^{-7}$ metres) studied by him on the French coast of the Mediterranean (e.g. in the Bay of Pierre-Formique) with the Strombus beach in the Mentone caves. The former type of beach contains a fauna very different from that of the Strombus layers, Strombus being absent, and all the fossils belonging to living species.

At the conclusion of his paper Prof. Boule referred to the three new human skeletons which have been recently discovered in the Grotte des Enfants. The first of these has been studied by MM. Gaudry and Verneau, and proves to be markedly Australoid in type. It was obtained in a bed containing Ursus spelaeus, Hyaena spelaea, Felis spelaea, \&c., and rested upon a bed containing molars of Rhinoceros mercki. It

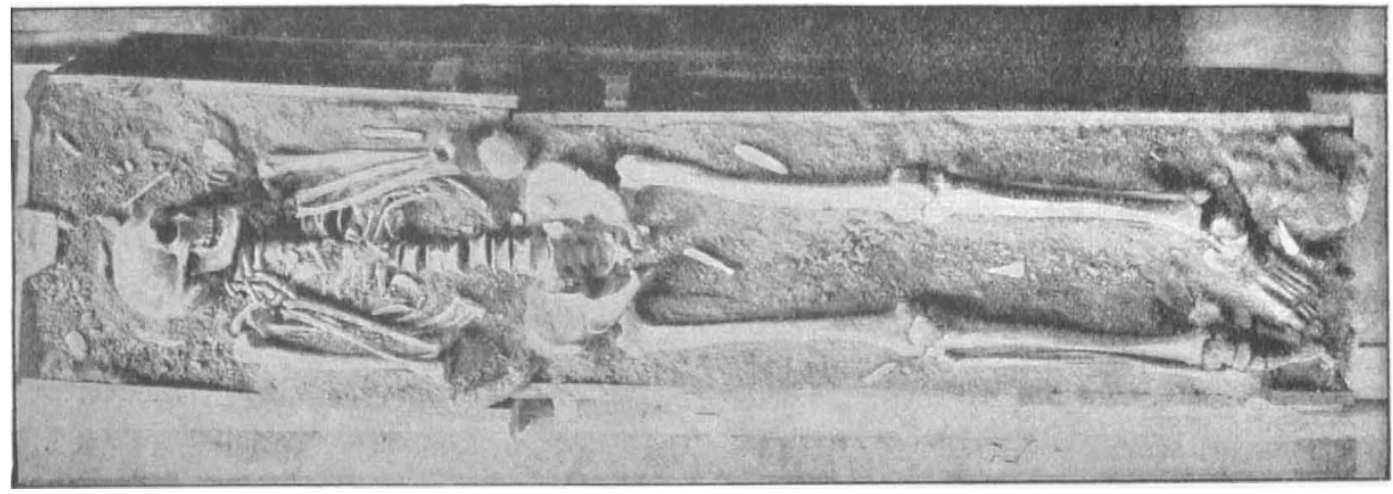

FiG. I.--Skeleton from the Grotte des Enfants.

Strombus mediterraneus, which has been regarded as characteristic of the raised beaches of the Quaternary period in the Mediterranean area. But the Prince's cave contains other traces of marine action of a much earlier date. In its upper part, at a height of 28 metres, there is a calcareous encrustation due to the action of the waves, below which the wall of the cavern is perforated by boring molluscs. The sequence of events is therefore explained by Prof. Boule as follows :-

The sea formerly stood at the 28 -metre level, and then gradually retired until it stood at a height of 7-8 metres. At this level the shell deposit was laid down on the floor of the cavern. Subsequently the movement of elevation was continued. Its extent is difficult to determine, but the oceanographical researches of the Prince of Monaco have shown that there extends along the rochers rouges at a slight depth an extensive submarine platform. This suggests that the movement-whether of the land or of the sea-continued until there was laid bare between the sea and the present irregular shore line a plain sufficiently extensive to become the home of such large animals as elephants, hippopotami, and rhinoceroses, for which the present topography allows no space. It is at least certain, according to Prof. Boule, that the NO. 1838 , VOL. 7 I] must therefore belong to the earlier part of the Quaternary period. The second skeleton was found about 0.60 metre above the first, and was accompanied by remains of the same species of mammals. The third skeleton, on the other hand, found 6 metres above the first, seems to belong to the period of the reindeer, that is, to the end of the Quaternary epoch.

\section{THE SCIENTIFIC EXPLORATION OF LAKE TANGANYIKA.}

THE committee for the scientific exploration of Lake Tanganyika (consisting of Sir John Kirk, Dr. Sclater, Sir W. Thiselton-Dyer, Prof. Lankester, Dr. Boulenger, and Mr. J. E. S. Moore) has lately received news of the progress of its envoy, Mr. W. A. Cunnington, who left England in March, I904, under directions to continue the researches carried out by Mr. J. E. S. Moore during his two expeditions to Lake Tanganyika. Proceeding by the Zambesi and Shiré route, Mr. Cunnington was most kindly received at Zomba by Sir Alfred Sharpe, who granted him the assistance of two native collectors. Mr. Cunnington had instructions to devote his special attention to the lacustrine flora and fauna of Lake 
Tanganyika, and, as he passed up Lake Nyassa, began his investigations in that lake, in order to be able to compare its products with those of Tanganyika. On Lake Nyassa Mr. Cunnington was able to get a good number of tow-nettings from different parts of the lake's surface, and obtained, on the whole, a large quantity of its characteristic phytoplankton, besides a considerable amount of zooplankton, consisting mostly of Copepoda, Cladocera, and insect-larvæ. The temperature of the water of Lake Nyassa was observed to fall seldom below $70^{\circ}$, while the temperature at 76 fathoms below the surface was ascertained to be about three degrees higher.

$\mathrm{Mr}$. Cunnington arrived at Karonga, at the head of Lake Nyassa, at the end of June, r904, and travelled on to Tanganyika by the ordinary route of the Stevenson road. His last letters from Tanganyika are dated at Vua, on October 29, 1904. He had obtained a dhow from Ujiji, which enabled him to make his stay at different places on the lake longer or shorter according as he found much or little to collect. A good series of fishes had been preserved, and many freshwater crustaceans. As regards the vegetable life, Mr. Cunnington had been much struck by the near resemblance of all the forms obtained in Tanganyika to those which he had collected in Nyassa, though he could not, of course, say that they were specifically identical. From Vua, Mr. Cunnington had arranged to cross to the east coast of the lake, and to go some distance further north before returning to the western shore. Mr. Cunnington may be expected to return to England before the end of the year.

\section{NOTES.}

Sir James Dewar has presented the proceeds of the Gunning prize, amounting to one hundred guineas, recently awarded to him by the Royal Society of Edinburgh, as a contribution to the fund for the encouragement of research, now being founded in the University of Edinburgh in memory of the late Prof. Tait.

WE regret to learn from the London branch of the Zeiss optical firm that Prof. Abbe, of Jena, died a few days ago. We also announce with regret the death of M. Paul Henry, astronomer at the Paris Observatory. His brother, M. Prosper Henry, with whom he was associated for many years in celestial photography, died about eighteen months ago.

ThE Paris Société d'Encouragement pour l'Industrie nationale has awarded the grand prize of the Marquis d'Argenteuil to MM. Auguste and Louis Lumière for their photographic discoveries. M. Héroult has been awarded a grand gold medal for his works on electro-metallurgy.

The two Antarctic ships Terra Nova and Morning were sold at Portsmouth on January ir. Messrs. W. Ziegler and Co., New York, bought the Terra Nova for $9600 l$., and she will probably be used for North Polar exploration. The Morning was sold for 1600 . The Discovery has been sold privately to the Hudson's Bay Company for Io,oool.

M. L. Bonnamère has been elected president for 1905 of the Prehistoric Society of France.

THE death is announced of Dr. Anton Müttrich, professor of physics and mathematics in the Academy of Forestry at Eberswald.

Sir William Tiisselton-Dyer, K.C.M.G., will take the chair at a lecture to be delivered at the West India
Committee Rooms, Seething Lane, on Wednesday, January 25 , by $\mathrm{Mr}$. W. G. Freeman, superintendent of the colonial economic collections at the Imperial Institute, on "The West Indian Fruit Industry."

THE next competition for the Howard medal of the Royal Statistical Society will take place in the ensuing session. The essays must be sent in on or before June 30 . In addition to the medal, a grant of $20 l$. will be awarded to the successful competitor. The subject is :- "A Critical Inquiry into the Comparative Prevalence of Lunacy and other Mental Defects in the United Kingdom during the Last Fifty Years."

ThE death is announced of Mr. T. W. Shore, author of a number of papers on geological and archæological subjects. Mr. Shore was for a long time resident at Southampton, where he acted as curator of the Hartley Institution and secretary of the Hampshire Field Club. At the Southampton meeting of the British Association in 1882 he was one of the secretaries of the section of geology. On removing to London, he founded the Balham Antiquarian Society, and became its secretary; he was also secretary of the London and Middlesex Archæological Society.

WE have received a letter from Mr. C. E. Stromeyer, of Manchester, in which he suggests that irregularities of the earth's surface might be detected by special observations for determining the position of the northern and southern limits of totality during the coming total solar eclipse of August next. Unfortunately there are many practical difficulties in the way which the author has not discussed, but he makes one suggestion which might be carried out. He proposes to place soldiers at short distances along the northern and southern borders of the shadow's path, who, by marking the positions where the eclipse was total, might determine with greater accuracy than is known the breadth of the moon's shadow.

A Correspondent writes:-The death of Dr. Thomas Woods occurred on January 5 in Birr (or Parsonstown). Dr. Woods was born in February, $\mathrm{I}_{8} \mathrm{I}_{5}$, and graduated as doctor of medicine in Glasgow in 1838 . He spent all his long life as a medical practitioner and as medical officer of the union and dispensary in Birr. So it is, perhaps, not to be wondered at that his scientific work belonged largely to a former generation. $\mathrm{He}$ was a chemist, and as such took part in the early development of photography, originating in the 'forties a new wet plate process, the "catalysotype," a detailed description of which may be found in Hunt's " History of Photography." In $18_{52}$ and $18_{53}$ he published in the Philosophical Magazine some original observations on the heat developed by chemical combination, and defended with considerable success his claim of priority against Andrews and Joule. He was a man of remarkable ability and astoundingly general scientific interest, and it is much to be regretted that circumstances kept him in a small country town, and that his professional duties prevented him from adding further to scientific knowledge. He continued mentally and bodily fresh to the very end, ever eager to hear of the latest scientific discoveries, and Birr feels distinctly the poorer for his loss.

A Reuter message from Christiania states that at Nesdal, north of Bergen, on Sunday, a mass of rock slipped into the Loenvand Lake. A wave of water twenty feet high, which resulted from the fall, swept the neighbourhood, carrying away houses, people, and cattle. 